\title{
Other people's money: The profit performance of Bangladeshi family dominated banks
}

DOI:

10.1016/j.jbef.2018.11.005

Document Version

Accepted author manuscript

Link to publication record in Manchester Research Explorer

\section{Citation for published version (APA):}

Mahbub, T., Matthews, K., \& Barker, K. (2019). Other people's money: The profit performance of Bangladeshi family dominated banks. Journal of Behavioral and Experimental Finance.

https://doi.org/10.1016/j.jbef.2018.11.005

\section{Published in:}

Journal of Behavioral and Experimental Finance

\section{Citing this paper}

Please note that where the full-text provided on Manchester Research Explorer is the Author Accepted Manuscript or Proof version this may differ from the final Published version. If citing, it is advised that you check and use the publisher's definitive version.

\section{General rights}

Copyright and moral rights for the publications made accessible in the Research Explorer are retained by the authors and/or other copyright owners and it is a condition of accessing publications that users recognise and abide by the legal requirements associated with these rights.

\section{Takedown policy}

If you believe that this document breaches copyright please refer to the University of Manchester's Takedown Procedures [http://man.ac.uk/04Y6Bo] or contact uml.scholarlycommunications@manchester.ac.uk providing relevant details, so we can investigate your claim.

\section{OPEN ACCESS}




\title{
Other People's Money: The Profit Performance of Bangladeshi Family Dominated Banks
}

(Revised) November 2018

\begin{abstract}
Studies in developed economies show that family-owned non-financial firms outperform others, explained by agency theory and protection of family capital. Findings in emerging economies are equivocal, while studies of family domination and banks' performance are scant. This paper examines the profit-performance of family-dominated banks in Bangladesh under competing hypotheses of bank-market structure. Using panel estimation, we model the profit-performance of banks and show that the principal drivers are costs, efficiency and non-performing loans. Family-dominated banks are less efficient and less profitable. The sources of weaker performance are higher non-performing loans and higher costs, with indirect evidence of poor corporate governance.
\end{abstract}

Keywords: Bangladesh Banking Market, Profit Performance, Family Dominated Banks, Corporate Governance

JEL Codes: G21, G28

Acknowledgments: We are grateful to the Editor and two anonymous reviewers for helpful comments to improve the paper. As always, all remaining errors are ours entirely. 


\section{Introduction}

The global financial crisis has stimulated a decade of debate about the vulnerability and soundness of the banking system. The Basel committee on banking supervision has highlighted the central roles of corporate governance ${ }^{1}$ and internal control (Maati and Maati-Sauvez, 2012). Several studies have examined the relationship between ownership structure and bank performance (La Porta et al., 2002; Hasan and Marton, 2003; Berger et al., 2005; Bonin et al., 2005, Douma et al., 2006) with respect to differences in identity, concentration and resource allocation among owners, as well as their relative power on the board, incentives, and ability to monitor managers.

Mainly, researchers have examined the banking sectors of developed economies (Bonin et al., 2005; Weill, 2007), with less attention to the bank performance of emerging economies. This paper examines the Bangladesh banking system, which has a history of only half a century. The Bangladesh banking structure is important to understand because the financial system is heavily bank based. The government promotes the establishment of new banks through periodically issuing new licences. Furthermore, the ownership structure of the banks is more important in developing country economies where overall the protection of shareholders' rights is weak (Ayadi et al., 2011), including in Bangladesh.

Our data sample ${ }^{2}$ covers the private commercial banks in Bangladesh. They can be classified into three generations according to their year of incorporation. The earliest is known as generation 1 banks, and these are largely dominated by family owners. ${ }^{3}$ Generation 2 and 3

\footnotetext{
1 Corporate governance is a set of transparent relationships between an institution's management, its board, shareholders and other stakeholders; hence, involves composition and role of the board of directors, enhancement of shareholders value, protection of shareholders rights, the integrity of accounting practices and disclosure and internal control system (Al-Farooque et al., 2007).

${ }^{2}$ We deliberately choose the years between 2001 and 2012 for this paper to capture the full effect of generation 1,2 and 3 banks. From 2013-14, 9 new banks came into the industry which are classified as 4 banks. Data for these banks are not readily available.

${ }^{3}$ Different definitions of family-dominated firms have emerged in recent years, but there is no clear consensus on a definition. However, most interpretations highlight ownership, family involvement, family control and the intention of transferring the business to future generations as key components of what could be classified as family-dominated firms (Chrisman, Chua and Sharma, 2005).
} 
banks were consecutively incorporated a decade later. The performance of generation 1 banks relative to generation 2 and 3 banks is the focus of this paper.

We aim to test the hypothesis that banks with family-dominated ownership under-perform other commercial banks, as measured by profitability performance. Most previous studies have examined the performance of non-banking firms in terms of ownership, and the incentive structure that arises from the use of the owner's capital. This paper focuses on the ownership of banks, which deal with 'other people's money'.

In the case of Bangladesh, it is argued in the literature that one of the reasons for bank underperformance is due to weak corporate governance in the family-dominated banks (Reaz and Arun, 2006). To pre-empt our results, we find that the data is consistent with this interpretation of weak corporate governance coincident with family dominance. Our finding is also supported by primary data from a qualitative survey.

This paper is organised as follows. The next section reviews the literature on bank profitability, the Bangladesh banking system, governance, agency theory, and the role of family-dominated ownership. Section 3 analyses the dataset and describes the methods employed. Section 4 presents and explains the results. The final section explains our contribution and indicates paths for further research.

\section{Literature Review}

In developing financial markets, banking regulation evolved with the periodic introduction of laws and codes of corporate governance. In reality, due to the ineffective implementation of regulation and improper evaluation of corporate governance, many banks have indulged in irregular activities that hamper their efficiency and profitability (Matama, 2005). This section provides an overview of the banking structure of Bangladesh and highlights the concept of bank profitability, corporate governance and the importance of ownership composition on bank 
performance in a developing country. Banking research has not focused heavily on this type of economic and political setting to date.

\subsection{Overview of the Banking Structure of Bangladesh}

In Bangladesh, the banking sector accounts for most of the total financial assets. In 2012, the banking sector of Bangladesh consisted of 4 state-owned commercial banks, 5 specialized development banks, 30 private commercial banks and 9 foreign commercial banks. The main assets of all banks are loans, advances and investment in government securities, while the main liabilities are time and demand deposits. Prior to 1982, the state-owned commercial banks dominated; after privatization and the emergence of the private commercial banks, the relative position of the state-owned commercial banks diminished.

Private commercial banks were established during the 1980s. They are classified under two categories: conventional and Islamic Shariah based. In 2012, 30 conventional private commercial banks operated and 7 were Islamic. The private-commercial banks are classified into 3 generations, based on their year of establishment. Generation 1 are those established between 1982 and 1990. At this time, ownership and control was transferred from the government to the private sector. Generation 2 were established between 1991 and 1998 and generation 3 between 1998 and 2001. In total, 8 banks are considered as $1^{\text {st }}$ generation private commercial banks where 6 are conventional, and 2 are Islamic Shariah based. (Appendix 1 presents a classification of the scheduled banks).

It is arguable that the speed of transformation of the banking sector meant that poor training and weak regulation provided the first-generation banks with little in the form of guidance on lending criteria or proper corporate governance. The pre-reform system for the banks stressed disbursements rather than recoveries and the accounting and debt collection systems that the first-generation banks inherited were probably inadequate. It became more common for borrowers to default on loans than to repay them; the lending system was simply disbursing grant assistance to private individuals who were poorly qualified for loans. The rate of recovery of agricultural loans was only 27 per cent in 1986 (Gregory and Adams, 1986 and Ahmed, 1986) 
and the rate for industrial loans was even lower. ${ }^{4}$ On the other hand, the lending interest rates on priority sectors were kept deliberately low, which did not cover the risk and cost (Chowdhury and Ahmed, 2009; Islam et al, 2013; Islam et al, 2014). Thus, interest ceilings and financial repression was the main cause of poor performance resulting in high non-performing loans and overall lower profitability at that time.

Pressure from the International Monetary Fund (IMF) resulted in the Banking Companies Act 1991, which strengthened internal bank management and credit discipline. Following its implementation, the rate of growth of assets of the banking system increased rapidly. ${ }^{5}$ The $2^{\text {nd }}$ and $3^{\text {rd }}$ Generation banks introduced greater account transparency in keeping with the Act, and instituted tighter risk management (Chowdhury and Ahmed, 2009; Islam et al, 2014). In 2012, a total of 30 private commercial banks existed with 7,664 branches. Table 1 outlines the distribution of assets, deposits and branches over the sample period.

Table 1: Distribution of Assets, Deposits and Branches of Private Commercial Banks

\begin{tabular}{|l|c|c|c|c|c|c|c|c|c|}
\hline & \multicolumn{3}{|c|}{ Generation 1 } & \multicolumn{3}{c|}{ Generation 2 } & \multicolumn{3}{c|}{ Generation 3 } \\
\hline & $\mathbf{2 0 0 1}$ & $\mathbf{2 0 1 2}$ & Increase & $\mathbf{2 0 0 1}$ & $\mathbf{2 0 1 2}$ & Increase & $\mathbf{2 0 0 1}$ & $\mathbf{2 0 1 2}$ & Increase \\
\hline & & & & & & & & \\
\hline Asset & 234,975 & $1,502,730$ & $540 \%$ & 147,932 & $1,363,798$ & $821 \%$ & 54,675 & $1,328,550$ & $2330 \%$ \\
\hline Deposits & 190,504 & $1,260,022$ & $561 \%$ & 122,714 & $1,148,772$ & $836 \%$ & 47,950 & $1,149,280$ & $2297 \%$ \\
\hline NPL* & $12 \%$ & $3 \%$ & -9 & $5 \%$ & $3 \%$ & -2 & $0.6 \%$ & $3 \%$ & 2.4 \\
\hline Branch & 980 & 1392 & 412 & 219 & 814 & 595 & 89 & 861 & 772 \\
\hline
\end{tabular}

*Non performing loans per assets

What Table 1 shows is that asset growth of the generation 2 and 3 banks far outpaced that of the generation 1 banks. The generation 1 banks began with a high Non-Performing Loans (NPLs)

\footnotetext{
${ }^{4}$ For much of the period following independence, Bangladesh inherited a repressed financial system in which the banks and other financial institutions were used as cheap sources of credit for export generation and import substituting industrialisation. During the period, control of interest rates, selective credit controls, regulations suppressing the development of money and capital markets, and the maintenance of an overvalued domestic currency contributed to financial repression, inefficiencies in investment, and non-repayment of loans by the borrowers (Rahman 2007). Furthermore, the banking system accumulated a large amount of classified loans due to politically motivated loan disbursement to unviable projects and corruption, weak risk management and poor portfolio management (Mujeri and Younus, 2009).

${ }^{5}$ Asset growth of the conventional commercial banks over the full period of this study was around $855 \%$.
} 
per asset rate but by the end of the period had converged on similar rates as the generation 2 and 3 banks. While branch increases by the generation 2 and 3 banks have outstripped the increase in the branch network of generation 1 banks, the latter retains a very large branch network that almost equals the sum of the former two. ${ }^{6}$

\subsection{Bank Profitability}

A wide range of papers explore the relationship between market structure, competition level, bank efficiency and profitability in the banking industry (Berger, 1995; Bikker and Bos, 2008, Guillén et al., 2014, Tabak et al., 2011). The theoretical basis for these studies is the Structure-Conduct-Performance (SCP) hypothesis. This assumes a direct positive link between market concentration and profitability and a negative correlation between concentration and competition (Bain, 1956). Studies of bank profitability also follow the approach of the Efficient Structure (EFS) hypothesis and the Relative Market Power (RMP) hypothesis (Gilbert, 1984). These hypotheses investigate whether a highly concentrated market causes collusive behaviour among the larger banks, resulting in superior market performance or whether it is the efficiency of larger banks that enhances their performance.

The SCP model is concerned with questions about the trilateral connection which relates the three poles of structure, conduct and performance. The traditional SCP framework suggests that the possibility of collusive behaviour increases when the market is concentrated in the hands of a few firms. The higher the market concentration is, the larger the profitability of the firms in that industry. The assumption is that the degree of concentration exerts a direct influence on the degree of competition among firms where a highly concentrated market will lower the cost of collusion and foster tacit and/or explicit collusion on the part of firms. Because of this collusion, all firms in the market will earn monopoly rents. The SCP hypothesis assumes a causal relationship running from the structure of the market to the price setting behaviour of firms and ultimately to profitability through the market power channel.

\footnotetext{
${ }^{6}$ It is also notable that the number of branches of the generation 2 and 3 banks are larger than generation 1 in 2012 , dismissing the scale inefficiency argument for the difference in profit-performance.
} 
Demsetz (1973) formulated an alternative explanation and proposed the Efficiency Structure (EFS) Hypothesis. Applied to the banking sector, this hypothesis stipulates that a bank which operates more efficiently than its competitors gains higher profits resulting from lower operational costs and holds an important share of the market. Since more efficient firms are expected to capture a higher market share, one way of distinguishing between the market power and efficient structure hypothesis is to include both market share and concentration in the profitability equation. If concentration becomes insignificant, this goes against the SCP hypothesis and indicates that market share has influence on profitability.

In contrast to the efficient structure hypothesis, the Relative Market Power (RMP) hypothesis argues that banks with a higher market share and well-differentiated products exert more market power and earn higher profits, independently of how concentrated is the market (Shepherd, 1986). It is uniquely the banks a large market share and diversified products who exert their market power to determine prices and make profits. Consequently, under the RMP hypothesis, individual market shares accurately determine market power and market imperfections.

The RMP hypothesis is empirically supported when concentration introduced in the explanatory equations of performance is found to be non-significant in contrast to market share, which should be positively and significantly correlated with price and/or profitability. Nevertheless, it is not obvious that employing market structure in these equations produces unambiguous results. A bank with a strong position in the market may either reinforce its domination over the market or achieve a higher efficiency. The RMP hypothesis posits that the more efficient firms can earn supernormal profits (Lloyd-Williams et. al., 1994).

The empirical evidence for each of these hypotheses is mixed. Many studies find evidence in support of the hypothesis that market concentration enhances banks' profitability. In a review of studies Gilbert (1984) found that 32 out of 44 studies showed supporting evidence for the SCP. Since then numerous studies have confirmed this finding (Bourke, 1989; Molyneux and Thornton, 1992; Lloyd-Williams et. al., 1994). ${ }^{7}$ However, contrary findings by Gillini et. al. (1984), Smirlock (1985) and Evanoff and Fontier (1988) found evidence in support of the

\footnotetext{
${ }^{7}$ An alternative specification that examines price rather profit, Berger and Hannan (1989) find support for the SCP.
} 
efficient structure hypothesis, while studies of the relative market power hypothesis are unable to distinguish between competing hypotheses (Lloyd-Williams and Molyneux, 1994, and Molyneux and Forbes, 1995). Typically, researchers use external measures of efficiency as an independent variable to distinguish between the RMP and ESF hypotheses. ${ }^{8}$

Studies on bank profitability in Bangladesh reflect the consensus of mixed findings. Samad (2008) tests the SCP and ESF hypotheses and finds support for the ESF model. In contrast Ahamed (2012) using a 3-bank concentration ratio finds strong support for the SCP hypothesis which is supported by Sayeed et al (2012) who use a Herfindahl-Hirschman Index ${ }^{9}$ (HHI) measure of concentration.

\subsection{Ownership Concentration and Impact of Family Dominance on Profitability}

Ownership structure and its influence on firm's performance stems from Agency Theory. This is based on a principal-agent relationship between the owners and the managers where they differ in terms of preferences (Jensen and Meckling, 1976). Berle and Means (1967) argued that diffused shareholders influence their rights through the election of the Board of Directors. The literature on family-dominated firms discusses the potential hazards and benefits from a theoretical perspective (Fama and Jensen, 1983; Demsetz and Lehn 1985; Shleifer and Vishny, 1986) where the empirical evidence is still lacking and is often contradictory, as national corporate governance characteristics differ across countries. Research on U.S. family firms' performance concludes that family firms outperform non-family firms when family members serve as CEO (Anderson and Reeb, 2003). Positive results also have been reported for European countries (Sraer and Thesmar, 2007; Thomsen and Pedersen, 2000; Barontini and Capiro, 2006;

\footnotetext{
${ }^{8}$ For example, Scott Frame and Kamerschen (1997) use an econometrically estimated cost function to identify xefficiency (X-efficiency measures the optimal use of resources by a unit/firm that defines the benchmark for all others) AlMuharrami and Matthews (2009) employ Data Envelopment Analysis to measure both technical and scale efficiency in their examination of the SCP hypothesis for the Gulf Cooperation Council (GCC) economies.

${ }^{9}$ The Herfindahl-Hirschman Index (HHI) is a common measure of market concentration that is used to determine market competitiveness. It is calculated by squaring the market share of each firm competing in a market and then summing the resulting numbers. It can range from close to zero to 10,000 . The closer a market is to a monopoly, the higher the market's concentration (and the lower its competition). If, for example, there were only one firm in an industry, that firm would have $100 \%$ market share, and the HHI would equal 10,000, indicating a monopoly. If there were thousands of firms competing, each would have nearly $0 \%$ market share, and the HHI would be close to zero, indicating nearly perfect competition (Bourke, 1989).
} 
Andres, 2008) and for Japan (Mehrotra et al., 2013). However, the results from emerging markets are mixed (Khanna and Yafeh, 2007). As suggested by many studies (Bennedsen and Nielsen, 2010; Bertrand and Schoar, 2006; Claessens et al., 2002; Stewart and Hitt, 2012 and Westhead and Cowling, 1997), family-controlled firms in emerging markets often extract more private benefits, although they may be better than non-family firms in identifying valuable investment opportunities.

In contrast, Faccio et al. (2001) find that family firms managed by non-family members perform worse than those managed by family members. Miller et al. (2007) find that Fortune 1000 firms that are owned by families or employ relatives as managers never exhibit superior performance. Principally, family control may negate or significantly reduce agency problems by reducing the conflict between shareholders and managers, resulting in low information asymmetry and moral hazard issues (Jensen and Meckling, 1976). However, it can be argued that this line of reasoning does not extend to banks. Family domination in banks is different from the family ownership in non-bank firms because of the difference in the leverage of the bank firm relative to the nonbank firm. In the case of the non-bank firm, the family has equity invested in the enterprise and has an incentive to maximize performance and shareholder value. In the case of banks, the family is able to influence loan advances for personal and wider family benefit in excess of the equity invested. The expropriation of bank assets leads to low performance and profitability in the short term.

In the case of Bangladesh, family ownership in the corporate sector is widespread. ${ }^{10}$ For example, Sobhan and Werner (2003) note that 73 per cent of non-bank listed companies are family dominated. Muttakin (2012) notes that for the period 2005-2009, 64 per cent of non-bank, non-utility firms in Bangladesh can be classified as family dominated. Family ownership control is also documented by Rashid and Lodh (2008), using data on 94 non-financial firms listed on the Dhaka Stock Exchange from 2000-2009. Rashid (2011) finds support for the predictions of

\footnotetext{
${ }^{10}$ Indeed, family-dominated firms is the norm in Asia which raises tensions between the family shareholders and other shareholders (see Gunter Dufey, 'Corporate Governance in Asia - Challenges and Prospects', Presentation to the World Banking \& Finance Symposium, Bangkok, 14-14 December 2017)
} 
Agency Theory. Further confirmation of the Agency Theory is reported in Muttakin et al. (2014) in their study of 141 listed firms in Bangladesh. ${ }^{11}$

\subsection{Governance of Banks in Bangladesh}

Corporate governance in banks differs because of their unique capital structure of being the custodian of 'other people's money'. Banks are highly leveraged institutions where a bank's profit increases directly with the volume of lending. This also increases the probability of default. As banks' balance sheets are more opaque than non-financial firms', information asymmetries are larger with banks.

Many studies address the relationship between ownership and bank performance. ${ }^{12}$ Little has been researched, particularly in the emerging economies, on the effects of family-dominated ownership on bank performance. It can be argued that the leverage associated with conventional commercial banks leans towards the expropriation thesis rather than the maximisation of intergenerational wealth. Family-dominated banks are vehicles for the maximization of wealth for the wider family through the provision of "soft" loans (meaning easier loan conditions and interest rates than risk conditions warrant) to itself at the cost of lower shareholder value. In effect, this is a cross-subsidy from one part of the family wealth portfolio to another.

Surifah (2013) finds that banks with family-dominated ownership in Indonesia perform poorly compared with government and foreign-owned banks. Abdul-Rahman and Reja (2015) find only a weak negative relationship between family ownership and profitability. With respect to Bangladesh, there have been no studies that have examined family ownership dominance and bank performance.

\footnotetext{
${ }^{11}$ Using the share of the firm owned by the board Al-Farooque et al. (2007) find no relationship between ownership and performance but reverse causation. However, while recognizing the family-dominated nature of the board structure they do not explicitly measure family dominance.

${ }^{12}$ See for example Berger et al (2005) and Megginson (2005).
} 
Reaz and Arun (2006) focus on the governance practices of banks in Bangladesh. They report the practice of bank fund misuse by large block-share owners, who also can improperly dominate the audit and disclosure practices of the banks. These authors conclude that the major problem of bad governance in Bangladeshi banks is rooted in political and family interference. It is also argued that a lax legal system and low penalties inhibit the process of institutionalization of good governance in Bangladesh (Chowdhury, 2002). Furthermore, minority shareholder protection in Bangladesh is weak due to poorly developed legal and regulatory mechanisms.

Mahbub (2016) surveyed the Bangladesh banking sector and reported on the influence of families on credit provision decisions across generation 1 banks in the form of personal connection through family ties or through business networking. It was evident that in some of these banks more than half of the board members are from one family and that the Managing Director has diminished decision-making power. Senior employees commented that the family owners of generation 1 banks act possessively and undertake questionable financial transactions in the form of securing credit for favoured projects, bypassing the usual credit management process (A list of quotations is provided in Appendix 2).

Directors seek to maximize their own personal benefit and thus take actions that benefit themselves but are detrimental to shareholders (Tricker, 2009). Since regulation prohibits board members from taking loans from their own banks, they frequently channel favourable credit lines to their relatives, extended family members and friends. Qualitative research conducted with board members and managers of a sample of Bangladeshi banks reports that many of the board members are known to each other through family relationships, political connection or business networking where they work as a 'family team' and maintain a 'symbiotic relationship' 13 among themselves (Mahbub, 2016).

\footnotetext{
${ }^{13}$ A 'symbiotic' relationship exists between the directors of two banks when the director of $\mathrm{X}$ bank gives a loan to the directors of $\mathrm{Y}$ bank, while the $\mathrm{Y}$ bank directors reciprocate, allowing another loan from their bank in favour of the $\mathrm{X}$ bank's director or giving a percentage of the loan obtained from the $\mathrm{X}$ bank.
} 


\section{Data and Methodology}

The data set covers 34 banks of three generations. These account for more than $90 \%$ of the total bank assets at the end of 2012 (Bangladesh Bank Website, 2013). The sample is a balanced panel of 30 private commercial banks and 4 state-owned commercial banks from 2001-2012 or 408 bank years of data, comprising a complete set of three generations.

The sample deliberately excludes generation 4 private commercial banks post-2012. The timeframe of the analysis is motivated by the availability and continuity of information. Additionally, the Bangladeshi banking system was resilient during the global financial crisis of 2007-2008, the banks withstanding the effects of the crisis relatively well (Kamarudin et al, 2016).

The present study is based on secondary data. The source of bank-specific financial data is Bankscope International Bank Database ${ }^{14}$ produced by the Bureau van Dijk. This provides banks' balance sheets and income statements. Some missing data were obtained from the balance sheets and income statements of annual reports ${ }^{15}$ and websites. All the accounting information is consolidated on December of each year.

As a measure of profitability, both return on assets (ROA) and return on equity (ROE) have been widely used as a dependent variable. ${ }^{16}$ In the case of Bangladesh, the incidence of negative profits and negative equity for a number of banks made ROE unreliable and thus we concentrate on ROA. The independent variables used in estimation are separated into bank-specific and industry-specific variables. All the variables are defined in Table 2 below. This also presents a snapshot of their descriptive statistics. As a novel feature, one of the variables, X-efficiency

\footnotetext{
${ }^{14}$ BankScope is the main source which provides data for a large number of banks in many countries of the world in the form of balance sheets, income statements, various ratios and ownership information.

${ }^{15}$ While annual reports published by various banks served as a complementary source of data, limitations exist with regard to accessibility of these reports and adequacies of the range of information, depending on the operative patterns and practices of various banks.

${ }^{16}$ See Grier and Smallwood (2007), Goddard et al. (2004) etc.
} 
$(\mathrm{EFF})$, is estimated using a bootstrap method in Data Envelopment Analysis with operational costs and fixed assets as inputs and net interest revenue and non-interest revenue as outputs. ${ }^{17}$

Table 2: Data Definition and Summary Statistics 2001-2012

\begin{tabular}{|c|c|c|c|c|c|c|c|}
\hline \multicolumn{2}{|c|}{ Measures } & Definitions & Notation & Mean & SD & Min & Max \\
\hline \multicolumn{2}{|c|}{ Profitability } & Net profit (Before Tax)/ Total & ROA & 0.9434 & 2.363 & -21.97 & 6.06 \\
\hline \multirow{5}{*}{ 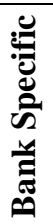 } & Credit Risk & Net NPL / Total Loans & NPLRAT & 0.1024 & 0.2589 & 0 & 4.273 \\
\hline & Capital Adequacy & Equity /Total Assets & EQTA & 0.0587 & 0.0869 & -0.7721 & 0.6887 \\
\hline & X- Efficiency & Technical Revenue Efficiency & EFF & 0.8415 & 0.1807 & 0.1145 & 1 \\
\hline & Management costs & Operational expenses/ Assets & OHEFRAT & 0.0228 & 0.0124 & 0 & 0.1852 \\
\hline & Family-board & Gen 1 Banks $=1$, others $=0$ & GEN1 & 0.3236 & 0.4684 & 0 & 1 \\
\hline \multirow{3}{*}{ 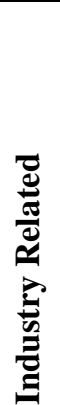 } & SOCB & $\begin{array}{l}\text { Government Banks denoted as } \\
1 \text { while others } 0\end{array}$ & OWNRSP & 0.1176 & 0.3226 & 0 & 1 \\
\hline & Concentration & $\begin{array}{l}\text { Concentration Ratio of } 5 \\
\text { Banks (The assets of the } 5 \\
\text { largest banks defined by asset } \\
\text { size divided by the total assets } \\
\text { of all banks in any given year) }\end{array}$ & CR5 & 48.05 & 6.658 & 37.21 & 57.98 \\
\hline & Market Share & $\begin{array}{l}\text { The share of an individual } \\
\text { bank's assets out of all banks } \\
\text { in any given year. }\end{array}$ & MS & 0.0294 & 0.0361 & 0 & 0.2445 \\
\hline
\end{tabular}

At the outset we identify differences in the raw measures of performance between Generation 1 banks and the rest in the sample. Table 3 shows the mean values of the measures of performance of banks in the sample (ROA, NPL ratio, cost-income ratio (CIRATIO), and Technical Efficiency (EFF) the latter obtained from the bootstrap Data Envelopment Analysis), separated by generation 1 and the rest, and including a Mann-Whitney test for differences in the separation.

Table 3: Performance Indicators: Two sample Mann-Whitney test

\begin{tabular}{|l|l|l|l|l|}
\hline & ROA\% & NPLRAT\% & CIRATIO\% & EFF \\
\hline Mean Total & 0.943 & 10.2 & 53.0 & 0.842 \\
\hline Mean GEN 1 & 0.563 & 14.3 & 70.1 & 0.745 \\
\hline Mean Rest of sample & 1.125 & 8.3 & 44.7 & 0.888 \\
\hline Z statistic & $5.16^{* * *}$ & $-9.28 * * *$ & $-7.81 * * *$ & $7.99 * * *$ \\
\hline
\end{tabular}

*** Significant at the $1 \%$-level

\footnotetext{
17 X-efficiency measures the optimal use of resources by a unit/firm that defines the benchmark for all other units/firms operating in the same space. For a full explanation of the use of Data Envelopment Analysis to construct this measure see Sherman and Gold (1985).
} 
It is clear from Table 3 that significant differences exist between the pool of generation 1 banks and the rest of the banking population in terms of profitability, NPLs, cost and efficiency and technical efficiency. The mean ROA for generation 1 banks is significantly lower than it is for the rest of the sample, as is the measure of efficiency. Similarly, the NPL ratio and cost-income ratio are significantly higher for the generation 1 banks than for the rest of the sample. This alone provides a prima facie case of difference in performance between the generation 1 banks and the rest that warrants deeper investigation.

\section{Empirical Results}

The empirical model on the determinants of banks' profitability is measured based on the return on assets (ROA) on balanced panel data where all the variables are observed for each crosssection and each time period. In this study, for determining factors of bank profitability, bankspecific variables and industry-specific variables are estimated. The general model that follows the framework of Smirlock (1985), Scott-Frame and Kamerschen (1997) and others is shown in equation 1 which is extended below by including bank-specific variables -

$\pi_{i, t}=\alpha_{0}+\alpha_{1} \operatorname{CR} 5+\alpha_{2} M S_{i, t}+\alpha_{3} E F F_{i, t}+\sum_{j=1}^{m} \beta_{j, t-p} X_{j, i, t-p}+\sum_{k=1}^{n} \gamma_{k, t-p} G E N 1 * X_{k, i, t-p}+u_{i, t}$

Equation (1) is a reduced form specification and differs from Smirlock (1985) and Scott-Frame and Kamerschen (1997) only in the choice of bank-specific variables, identified in Table 3. Here, $i=1 . .34$ banks, $j$ is the number of bank-specific variables, $k$ is the subset of bank-specific variables that differ between generation 1 and the rest, and $t$ is time 2002-2012. We allow for the effect of lags of order ' $p$ ' in the bank-specific variables. The specific function identifies the separate impact of generation 1 banks through the interaction terms $G E N 1 * X_{k, i, t-p}$. Where $\pi_{i, t}$ represents ROA of bank $i$ in year $t$, the first three independent variables are as in Table 2 above, $X_{j, i, t}$ are the $j$ bank variables, GEN1 represents the dummy variable that identifies the generation 1 (family dominated boards) and $X_{k, i, t}$ are a subset of the bank-specific variables. 
If the traditional SCP hypothesis holds $\alpha_{1}>0$ and $\alpha_{2}=0$. If the ESF model holds $\alpha_{1}=0$ and $\alpha_{2}>0$. If the RMP hypothesis holds independently of $M S_{i, t}$ then $\alpha_{3}>0$. If generation 1 banks differ from Generation $2 \& 3$ in terms of higher NPLs and higher operational costs, then the sum of the coefficients associated with the interactive variables $G E N 1 * X_{k, i, t-p}$ will be negative. More precisely;

Hypothesis: $\sum_{k=1}^{n} \gamma_{k, t-p}<0$

Table 4 presents our results.

Table 4: Panel estimation; Dependent variable ROA; 'p' values in parenthesis

\begin{tabular}{|c|c|c|c|}
\hline Variable & Equation 1 & Equation 2 & Equation 3 \\
\hline \begin{tabular}{|l} 
NPLRAT \\
\end{tabular} & $-1.422(0.001)^{* * *}$ & $-0.833(0.006)^{* * *}$ & $-0.823(0.005)^{* * *}$ \\
\hline NPLRAT(-1) & $0.507(0.131)$ & $1.06(0.001)^{* * *}$ & $1.157(0.000)^{* * *}$ \\
\hline EQTA & $14.88(0.000)^{* * *}$ & $14.04(0.000)^{* * *}$ & $13.56(0.000)^{* * *}$ \\
\hline CR5 & $0.011(0.073)^{*}$ & $-.004(0.669) * *$ & $0.029(0.021)^{* *}$ \\
\hline MS & $-2.18(0.305)$ & $-1.73(0.766)$ & $-3.08(0.580)$ \\
\hline EFF & $0.963(0.580)$ & $.334(0.487)$ & $0.963(0.065)^{*}$ \\
\hline OHEFRAT & $-61.11(0.000)^{* * *}$ & $-70.46(0.000)^{* * *}$ & $-71.41(0.000)^{* * *}$ \\
\hline OHEFRAT(-1) & $53.38(0.000)^{* * *}$ & $68.57(0.000)^{* * *}$ & $69.82(0.000)^{* * * *}$ \\
\hline GEN1*NPLRAT & $-5.91(0.001)^{* * *}$ & $-8.95(0.000) * * *$ & $-7.553(0.000) * * *$ \\
\hline GEN1*NPLRAT(-1) & $3.08(0.062)^{*}$ & $4.71(0.002)^{* * *}$ & $3.79(0.014)^{* *}$ \\
\hline GEN1*OHEFRAT & $-12.19(0.351)$ & $-59.94(0.000)^{* * *}$ & $-79.32(0.000) * * *$ \\
\hline GEN1*OHEFRAT(-1) & $18.07(0.165)$ & $-76.28(0.000)^{* * *}$ & $-36.021(0.001)^{* * *}$ \\
\hline Bank Fixed Effects & No & Yes & Yes \\
\hline Year Fixed Effects & No & No & Yes \\
\hline No of Observations & 372 & 372 & 372 \\
\hline Fitness & $\operatorname{Chi}(12)=526 * * *$ & $\mathrm{~F}(12,326)=75.23^{* * *}$ & $\mathrm{~F}(21,317)=49.04 * * *$ \\
\hline Test for Fixed Effects & - & $\mathrm{F}(33,326)=4.98^{* * *}$ & $\mathrm{~F}(33,317)=5.40 * * *$ \\
\hline Chow test Break $=2008$ & $\mathrm{~F}(12,348)=4.20 * *$ & $\mathrm{~F}(44,284)=3.22 * *$ & $F(12,348)=0.714$ \\
\hline Chow test Break $=2007$ & $\mathrm{~F}(12,348)=5.24 * *$ & $\mathrm{~F}(44,284)=2.25^{* *}$ & $\mathrm{~F}(12,348)=0.99$ \\
\hline
\end{tabular}

*** Significant at the 1\%-level; $\quad$ ** Significant at the 5\%-level; * Significant at the 10\%-level

The second column shows the results from pooled estimation, the third from one-way fixed effects (bank fixed effects) and the fourth column from two-way fixed effects (bank and year fixed effects). The final row of the third and fourth columns shows the $\mathrm{F}$ test for the deletion of the bank fixed effects which rejects its removal. 
A Chow test for a structural break at either 2008 or 2007 coinciding with the Global Financial Crisis shows that the pooled or one-way fixed effects model, is not stable over the full sample period. This can give rise to invalid inference and inconsistent estimates of the parameters. A full treatment of multiple structural breaks in the model is beyond the scope of this paper ${ }^{18}$, however the year dummies absorb all the potential structural changes over time so the results of column 4 reject any specific structural break associated with Global Financial Crisis. The results of equation 3 show that main results are maintained.

A variant of the Chow test using slope dummies for break points in 2008 and 2007 show that the model with time dummies is stable. This is because the time dummies absorb all the time-variant heterogeneity in the model including the GFC. It can be seen from column 4 that while the quantitative values of the parameters change from column 3, the qualitative story remains the same for the main variables of interest. The net effect of the interaction variables with GEN1 is negative even with time dummies.

Therefore, concentrating on the two-way fixed effects results (equation 3), we cannot reject the traditional SCP hypothesis. The concentration CR5 variable exerts a positive effect on profitability, the MS variable is statistically insignificant, but the efficiency variable EFF is only significant at the 10\%-level. ${ }^{19}$ Thus, in keeping with Ahamed (2012) we find some support for the SCP hypothesis for Bangladesh banks. In contrast to Samad (2008), we find no support for the ESF hypothesis. The efficiency variable is positive but not statistically significant which means that our results do not provide any strong evidence that can distinguish between the ESF and the RMP hypothesis.

Along with Athanasoglu et al (2008) for the Greek banking system, we find that the capital exerts a positive effect on profits. A higher equity-asset ratio can follow up more profitable

\footnotetext{
${ }^{18}$ See Baltagi et al (2016)

${ }^{19}$ Similar results are obtained if the CR5 variable is substituted for a measure of concentration based on a Herfindahl Hirschman Index for bank assets.
} 
business opportunities with a fatter capital belt to absorb potential losses. Operating expenses measured by the ratio of operating expenses to assets has the expected negative effect on profitability and as expected the NPL ratio has a negative effect on profits.

Importantly for our main argument, the sum of the current and lagged interactive terms (GEN1*NPLRAT and GEN1*OHEFRAT) shows a negative effect on profitability confirming the main hypothesis that allowing for all other factors the generation 1 banks perform poorly against the other commercial banks. The two specific variables identify the source of the difference in performance. Family dominated boards have higher NPLs and higher overhead costs than other banks. ${ }^{20}$

Table 5 presents some additional results as tests for robustness. Here we re-parameterise the specification to recognise the dynamics in the specification of the base-case and include interaction terms with the ownership dummy which distinguishes private from state-owned banks. We also include the change in the equity ratio (EQTA) and its lag along with interactions with government ownership and the NPL ratio and the overheads ratio. Our main results are unchanged. Basically, the interaction terms with the generation 1 bank dummy and the NPL ratio and overheads ratio exert on balance an overall negative effect, confirming the hypothesis that generation 1 banks underperform other banks by having higher NPLs and higher costs.

Table 5: Tests for Robustness; Dependent Variable ROA; 'p' Values in Parenthesis

\begin{tabular}{|l|l|l|l|}
\hline Variable & Equation 1 & Equation 2 & Equation 3 \\
\hline & & & \\
\hline$\Delta$ NPLRAT & $-0.862(0.000)^{* * *}$ & $-0.862(0.000)^{* * * *}$ & $-0.868(0.000)^{* * *}$ \\
\hline$\Delta$ EQTA & $17.15(0.000)^{* * *}$ & $17.20(0.000)^{* * *}$ & $16.81(0.000)^{* * * *}$ \\
\hline EQTA(-1) & $9.58(0.000)^{* * *}$ & $9.60(0.000)^{* * *}$ & $9.42(0.000)^{* * *}$ \\
\hline CR5 & $0.031(0.010)^{* * *}$ & $0.031(0.009)^{* * *}$ & $.032(0.006)^{* * *}$ \\
\hline MS & $-5.96(0.268)$ & $-.6 .99(0.196)$ & $-5.44(0.307)$ \\
\hline EFF & $0.994(0.045)^{* *}$ & $1.01(0.041)^{* *}$ & $1.086(0.027)^{* *}$ \\
\hline
\end{tabular}

${ }^{20}$ It should be noted that the use of time dummies makes it difficult to directly test for a structural break for the Global Financial Crisis (2007-2008), but the significance at the 5\% of some of the years (not shown) indicates intercept shifts in time. 


\begin{tabular}{|l|l|l|l|}
\hline$\Delta$ OHEFRAT & $-62.39(0.000)^{* * *}$ & $-62.35(0.000 * * *$ & $-62.43(0.000)^{* * *}$ \\
\hline GEN1*NPLRAT & $-8.49(0.000)^{* * *}$ & $-7.79(0.000)^{* * * *}$ & $-7.36(0.001)^{* * *}$ \\
\hline GEN1*NPLRAT(-1) & $3.81(0.012)^{* *}$ & $2.65(0.000)^{* * *}$ & $3.21(0.034)^{* *}$ \\
\hline GEN1*OHEFRAT & $-81.42(0.000)^{* * *}$ & $-81.68(0.000)^{* * *}$ & $-15.85(0.525)$ \\
\hline GEN1*OHEFRAT(-1) & $-34.27(0.000)^{* * *}$ & $-35.83(0.000)^{* * *}$ & $-36.91(0.000)^{* * *}$ \\
\hline OWNRSP*NPLRAT & $0.672(0.785)$ & & $0.332(0.891)$ \\
\hline OWNRSP*NPLRAT(-1) & - & $2.306(0.298)$ & - \\
\hline OWNRSP*OHEFRAT & - & - & $-74.09(0.005)^{* * *}$ \\
\hline Bank Fixed Effects & Yes & Yes & Yes \\
\hline Year Fixed Effects & Yes & Yes & Yes \\
\hline No of Observation & 372 & 372 & 372 \\
\hline Fitness test & $\mathrm{F}(21,317)=56.67 * * *$ & $\mathrm{~F}(21,317)=56.90^{* * *}$ & $\mathrm{~F}(22,316)=55.65 * * *$ \\
\hline
\end{tabular}

*** Significant at the 1\%-level; ** Significant at the 5\%-level; * Significant at the 10\%-level

A valid criticism of our results is that a binary variable to identify family-dominated banks may capture other aspects of generation 1 banks that are not related to family influence on board decisions. A simple but imperfect measure of family dominance on the board of Directors would be to identify the proportion of board members that belong to a single family or a cluster of families $^{21}$. There are two problems with this measure. First, family influence may be greater than just the number of individuals (or proportion) on the board. A family member who is a strong Chairman of the board can create an atmosphere of 'groupthink' (Turner and Pratkanis, 1998). Second, on a practical matter, data on the composition of the board is not always provided consistently in the Annual Statements of the Banks, which is the basis of the data collected in this study.

However, for the years where the data is available we can identify the family members of a single unit or a cluster of 2-3 units. With generation 1 banks the available bank-years of data that provide information on family membership is 61 out of a maximum of 78 . With generation 2 and 3 banks, the available data was for 135 bank-years out of a maximum of 168 . This is an unbalanced panel that can raise issues of inference in panel estimation if the missing cells are not randomly distributed (see Wooldridge, 2009). However, while this is an incomplete set of data there are sufficient observations to evaluate the differences in board composition of the three generations of banks in terms of proportion of the board made up of family members. We conduct a Wilcoxon rank-sum test to verify if the generation 1 banks' proportion of family

\footnotetext{
${ }^{21}$ It can be argued that while family identity is distinct, in Bangladesh family clusters (more than one family on the board) will work as a single unit in recognition of the common objective of providing soft loans to each other's business interests.
} 
members on the board is from the same population as generation $2 \& 3$. Table 6 provides some statistics.

Table 6: Family Board Composition: Two-sample Wilcoxon rank-sum test

\begin{tabular}{|l|c|c|c|c|}
\hline Bank & Valid Observations & $\begin{array}{l}\% \text { of maximum } \\
\text { number of observations }\end{array}$ & $\begin{array}{l}\text { Mean number of } \\
\text { families on Board } \\
\text { per bank-year }\end{array}$ & $\begin{array}{l}\text { Mean \% family on } \\
\text { Board per bank- } \\
\text { year }\end{array}$ \\
\hline Generation 1 & 61 & $78 \%$ & 5.5 & $37.5 \%$ \\
\hline Generation 2 \& 3 & 135 & $80 \%$ & 0.8 & $4.3 \%$ \\
\hline z- statistic & - & - & - & $-9.53 * * *$ \\
\hline
\end{tabular}

*** Significant at the $1 \%$-level

It is clear that the null of common family board composition is decisively rejected. We suggest that our use of the binary variable GEN1 to identify family-dominated banks in this study is valid in the light of the result shown in Table 6.

\section{Conclusion}

This paper has examined the performance of family-dominated ownership of banks in Bangladesh within the context of the SCP-ESF-RMP models of bank profitability. The results are tantalising in that there would appear to be evidence of under-performance by familydominated banks in terms of profitability. Therefore, for banking firms, family ownership does not lead to enhanced performance in the case of Bangladesh. This study has also shed light on the conventional SCP-ESF-RMP hypotheses of bank profitability. In keeping with previous studies, the results provide some support for the SCP model and weak support for the RMP model, suggesting a more complex market structure performance relationship in the Bangladeshi banking industry.

The results show that the under-performance of generation 1 banks is consistent with the argument that family-dominated banks influence lending to maximise the welfare of the family group - hence the higher NPL history - for which we have some limited evidence from interviews. Also, family-dominated banks may encourage managerial 'feather bedding' by tolerating higher operational costs per asset. However, these suggestions are also consistent with the view that after privatization there was a learning period culminating in many mistakes, 
resulting in an overhang of NPLs for generation 1 banks that generation 2 and 3 banks were able to avoid.

The higher costs of the generation 1 banks could also be due to the wider branch network they inherited on privatization, which they have further increased. They may have inherited a heavy load of NPLs at the time of their inception, but these would have long been written-off before our data period. The difference between the NPL ratio with the other banks for the sample period examined will be new NPLs. Clearly, further research needs to be undertaken to isolate the family influence on the corporate governance of generation 1 banks.

Survey evidence (Mahbub 2016) suggests that family dominance on the Board has been used to override the credit committee and the process of due diligence to the detriment of bank performance. The results of this study are consistent with this view. Until deeper research is conducted, the results presented in this paper remain a significant finding which deserves further investigation and explanation. 


\section{References}

Abdul Rahman A N A and Reja A F M (2015), 'Ownership structure and bank performance', Journal of Economics, Business and Management, 3, 5, 483-487

Ahamed M (2012), 'Market structure and performance of Bangladesh banking industry: A panel data analysis', Bangladesh Development Studies, XXXV, 3, 1-17

Ahmed, Z U (1986) "Rural Banking in Bangladesh, A Brief Review" Agricultural Finance Program, Department of Agricultural Economics and Rural Sociology, The Ohio State University, Columbus, Ohio

Al-Farooque O, Van Zijl T, Dunstan K and Waresul Karim AKM (2007), 'Ownership Structure and Corporate Performance: Evidence from Bangladesh', Asia-Pacific Journal of Accounting and Economics, 14, 127-150

Al-Muharrami S and Matthews K (2009), 'Market Power versus Efficient-Structure in Arab GCC Banking', Applied Financial Economics, 19, 1487-1496

Anderson, R.C. and Reeb, D. M., (2003), "Board Composition: Balancing Family Influence in S\&P 500 Firms", Administrative Science Quarterly, Volume: 49 issue: 2, page(s): 209-237

Andres, C. (2008), "Large shareholders and firm performance - an empirical examination of founding-family ownership", Journal of Corporate Finance, Vol. 14, pp. 431-445

Athanasoglou P, Brissimis P and Delis M (2008), 'Bank-specific, industry-specific and macroeconomic determinants of bank profitability', Journal of International Financial Markets, Institutions \& Money, 18, 121-136

Ayadi, R., E. Arbak and W.P. de Groen, (2011), "Business Models in European Banking: A pre-and post-crisis screening”, Centre for European Policy Studies (CEPS), Brussels

Bain, J., (1956), "Barriers to New Competition” Cambridge, Mass.: Harvard University Press Bangladesh Bank (2003) Annual Report, [online]. Available from: www.bangladesh-bank.org [Accessed 31 December 2012]

Baltagi R. H., Feng Q., and Kao C, (2016), "Estimation of heterogeneous panels with structural breaks", Journal of Econometrics, 191, 176-195

Barontini, R. and L. Caprio (2005), "The effect of family control on firm value and performance: evidence from continental Europe", European Financial Management, Vol. 12, pp. $689-723$

Bennedsen, M., and Nielsen, K. M., (2010), "Incentive and entrenchment effects in European ownership", Journal of Banking \& Finance, Vol. 34, No. 9, PP. 2212-2229.

Berger A N (1995), 'The profit-structure relationship in banking-tests of market power and efficient-structure hypotheses', Journal of Money, Credit and Banking, 27(2), 404-431 
Berger A, and Hannan T (1989), 'The price-concentration relationship in banking', Review of Economics and Statistics, 71, 2, 291-299.

Berger A, Clarke G, Cull R, Klapper L and Udell G (2005), 'Corporate governance and bank performance: a joint analysis of the static, selection, and dynamic effects of domestic, foreign and state ownership', Journal of Banking and Finance, 29, 2179-2221

Berle, A. A., and Means, G. C., (1967), 'The Modern Corporation and Private Property' 2nd edn Harcourt, Brace and World, New York, ISBN 0-88738-887-6

Bertrand, M. and Schoar, A., (2006) "The Role of Family in Family Firms", Journal of Economic Perspectives, 20 (2): 73-96

Bikker, J.A. and Bos, J.W.B. (2008), "Bank Performance: A theoretical and empirical framework for the analysis of profitability, competition and efficiency", Routledge International Studies in Money and Banking, Routledge, London \& New York, 176 pages

Bonin, J. P., Hasan, I. and Wachtel, P. (2005), "Bank Performance, Efficiency, and Ownership in Transition Economies." Journal of Banking \& Finance, 29(1):31-53.

Bourke, P. (1989), 'Concentration and other determinants of bank profitability in Europe, North America and Australia', Journal of Banking and Finance 13, 65-79.

Chowdhury, A. (2002), "Politics, society and financial sector reform in Bangladesh", International Journal of Social Economies, 29(12), 963-988

Chowdhury, T.A. and Ahmed, K. (2009), "Performance Evaluation of Selected Private Commercial Banks in Bangladesh", International Journal of Business and Management, 4 (4)

Chrisman, J. J., Chua, J. H., and Sharma P., (2005), "Trends and directions in the development of a strategic management theory of the family firm", Entrepreneurship Theory and Practice, $29,555-576$.

Claessens, S., Djankov, S., and Lang, L. H. P. (2000). The separation of ownership and control in East Asian corporations. Journal of Financial Economics, 88(3), 554-580.

Claessens, S., S. Djankov, J. Fan, and L. Lang, (2002), "Disentangling the incentive and entrenchment effects of large shareholdings", Journal of Finance, 57, 2741-2771

Demsetz, H. (1973), 'Two Systems of Beliefs about Monopoly', in Goldschmid, H (ed.) Industrial Concentration: The New Learning, Boston: Little, Brown.

Demsetz, H. and Lehn, K., (1985) "The structure of corporate ownership: causes and consequences”, Journal of Political Economy, 93, 1155-1177

Douma S., Rejie G. and Rezaul K., (2006), "Foreign and domestic ownership, business groups, and firm performance: evidence from a large emerging market", Strategic Management Journal, 27, 637-657 
Evanoff, D. and D. Fortier (1988). 'Re-evaluation of the structure-conduct-performance paradigm in banking', Journal of Financial Service Research 1, 277-294.

Faccio, M. , Lang, L. H. P. , and Young, L., (2001). "Dividends and Expropriation", American Economic Review, 91(1): 54-78

Fama, E.F. and Jensen, M. (1983), "Agency problems and residual claims", Journal of Law and Economics, XXVI: 327-349.

Furfine, C. (2001), "Bank Portfolio Allocation: The impact of capital requirement, regulatory monitoring and economic conditions", Journal of Financial Services Research, 20:30-56

Gilbert, R. Alton (1984), 'Bank Market Structure and Competition: A Survey', Journal of Money, Credit and Banking, 4 - part 2, November, pp. 617-45.

Gillini T, Smirlock M and Marshall W (1984), 'Scale and scope economics in the multiproduct banking firm' Journal of Monetary Economics, 13, 393-405

Gregory GL and Adams DW (1986), ‘Agricultural Loan Recovery Problems in Bangladesh' Agricultural Finance Program, Department of Agricultural Economics and Rural Sociology, The Ohio State University [Available at: http://pdf.usaid.gov/pdf_docs/Pnaba364.pdf]

Grier, K.B. and Smallwood A.D. (2007), "Uncertainty and Export Performance: Evidence from 18 Countries", Journal of Money, Credit and Banking, Volume 39, Issue 4, Pages: 965-979, DOI: $10.1111 / \mathrm{j} .1538-4616.2007 .00053$

Guillén, A. J., Gomez, J., Crespo, A. and Guerrero, A., (2014), "Towards the Industrial Application of PHM: Challenges and Methodological Approach", In PHM Society European Conference

Hasan, I. and Marton, K. (2003), "Development and efficiency of a banking sector in a transitional economy: Hungarian experience", Journal of Banking and Finance, 27: 2249-2271.

Islam, M.A., Siddiqui, M.H., Hossain and Islam, M. R (2014), "Growth of Private Commercial Banks in Bangladesh", International Journal of Economics, Finance and Management Sciences, 2(1), 53-67

Islam, M.A., Siddiqui, M.H., Hossain, K.F. and Karim, L. (2013), "Performance Evaluation of the Banking Sector in Bangladesh: A Comparative Analysis", Business and Economic Research, Vol. 4, No. 1, ISSN 2162-4860 2014

Jensen, M. and Meckling, W. (1976) 'Theory of the Firm: Managerial Behavior, Agency Costs, and Ownership Structure'. Journal of Financial Economics, 3, pp. 305-360.

Kamarudin, F. , Sufian, F., and Nasir, A. M., (2016) "Global financial crisis, ownership and bank profit efficiency in the Bangladesh's state owned and private commercial banks" Contaduría y Administración, 61, 705-745 
Kaur, G. and Mishra, R. (2010), "Corporate governance failures in India: A study of Academicians perceptions", The IUP Journal of Corporate Governance, IX: (1): 99-112.

Kempf, A. and Ruenzi, S. (2008), "Family matters: Rankings within fund, families and fund inflows", Journal of Business Finance \& Accounting, 35(1/2), 177-199.

Khanna, T. and Yafeh, Y., (2007), "Business Groups in Emerging Markets: Paragons or Parasites?", Journal of Economic Literature, Vol. 45, No. 2, pp. 331-372

La Porta, R., Lopez-de-Silanes, F., Shleifer, A. and Vishny, R. (2002), "Government Ownership of Commercial Banks", Journal of Finance, 57: 256-301.

Lloyd-Williams, D., Molyneux, P. and J. Thornton (1994). 'Market structure and performance in Spanish banking.' Journal of Banking and Finance 18, 433-443.

Maati, J. and Maati-Sauvez, C., (2012), "Regulatory Governance Mechanisms in Banks", Bankers Markets \& Investors : an academic \& professional review, pp.43-58

Macey, J. and O'Hara, M. (2003), "The corporate governance of banks", Federal Reserve Bank of NY Economic Policy Review, April: 91-107.

Mahbub T (2016), The Performance of Bangladeshi Commercial Banks: The Role of Corporate Governance), University of Manchester, Unpublished PhD thesis

Matama, R. (2005) 'Corporate governance and financial performance of selected commercial banks in Uganda' Working Paper

Megginson W (2005), 'The economics of bank privatization', Journal of Banking and Finance, $29,1931-1980$

Mehrotra, V., Morck, R, Shim, J. and Wiwattanakantang, Y., (2013), “Adoptive expectations: Rising sons in Japanese family firms", Journal of Financial Economics, Volume 108, Issue 3, Pages 840-854

Miller, D., Miller, I. L. B, Lesterc, R. H. and Cannella Jr., A. A, (2007), "Are family firms really superior performers?" Journal of Corporate Finance, Volume 13, Issue 5, Pages 829858

Molyneux, P., and Forbes, W. (1995), 'Market Structure and Performance in European Banking', Applied Economics, Vol.27, pp.155-59.

Molyneux, P., and Thornton, J. (1992), 'Determinants of European bank profitability: A note' Journal of Banking and Finance 16, 1173-1178.

Morgan, D. (2002), "Rating banks: risk and uncertainty in an opaque industry", American Economic Review, 92(4), 874-888

Mujeri, M. K. and Younus, S. (2009) "An Analysis of Interest Rate Spread in the Banking Sector in Bangladesh" The Bangladesh Development Studies, Vol. 32, No. 4, pp. 1-33 
Muttakin M B, Khan A and Subramaniam N (2014), 'Family Firms, Family Generation and Performance: Evidence from an Emerging Economy', Journal of Accounting in Emerging Economies, 4, 2, 197-219

Muttakin, M. B. (2012), Family Firms, Board Structure, Political Connections and Performance: Evidence from Bangladesh, Deakin University, Unpublished PhD Thesis

Rahman, M.H (2007) 'Financial Development-Economic Growth Nexus in Bangladesh' Working Paper Series WP0707, Policy Analysis Unit, Bangladesh Bank

Rashid A (2011), 'Largest Blockholding and Firm Performance: Evidence from an Emerging Economy', International Research Journal of Finance and Economics, 65, 25-33

Rashid A and Lodh S C (2008), 'The Influence of Ownership Structures and Board Practices on Corporate Social Disclosures in Bangladesh', in Tsamenyi M and Uddin S (eds), Research in Accounting in Emerging Economies, 8, 211-237

Reaz, M. and Arun, T. (2006), "Corporate governance in developing economies: Perspective from the banking sector in Bangladesh", Journal of Banking Regulation, 7(1/2): 94-105.

Samad A (2008), 'Market structure, conduct and performance: Evidence from the Bangladesh banking industry', Journal of Asian Economics, 19, 181-193

Sayeed M A, Piyadasa E and Hoque M (2012), 'Bank profitability: the case of Bangladesh', International Review of Business Research Papers, 8, 4, 157-176

Scott-Frame W and Kamerscen D R (1997), 'The profit-structure relationship in legally protected banking markets using efficiency measures', Review of Industrial Organization, 12 $9-22$

Sherman H.D and Gold F (1985), 'Bank branch operating efficiency: evaluation with Data Envelopment Analysis', Journal of Banking and Finance, 9 (2), 297-315

Shleifer, A. and Vishny, R.W. (1986), "Large Shareholders and Corporate Control", Journal of Political Economy, 94(3,Part 1), 461 - 488

Smirlock, M. (1985). 'Evidence on the Non-Relationship between Concentration and Profitability in Banking' Journal of Money, Credit and Banking, 17(1): 69-83.

Sobhan F and Werner W (2003), 'Diagnostic Study of Existing Corporate Governance Scenario in Bangladesh', in Sobham F and Werner W, A Comparative Analysis of Corporate Governance in South Asia, Bangladesh Enterprise Institute

Sraer, D. and Thesmar, D. (2007), "Performance and Behaviour of Family Firms: Evidence from the French Stock Market", Journal of the European Economic Association, 5(4):709-751

Stewart, A. and Hitt, M.A. (2012) "Why Can't a Family Business Be More Like a Nonfamily Business? Modes of Professionalization in Family Firms", Family Business Review, Vol. 25, No. 1: 58-86 
Surifah (2013), 'Family control, board of directors and bank performance in Indonesia', American International Journal of Contemporary Research, 3, 6, 115-124

Tabak, B.M., Sttaub, R.B. and Souza, G. S. (2011) "Evolution of bank efficiency in Brazil: A DEA approach" European Journal of Operational Research, 202(1):204-213

Thomsen, S. and Pedersen, T. (2000) "Ownership structure and economic performance in the largest European companies”, Strategic Management Journal, Vol 21, Issue 6, pp 689 - 705

Tricker, R.I. (2009) Corporate Governance: Principles, Policies and Practices, An International Review, Oxford University Press

Turner, M.E. and Pratkanis, A.R. (1998) "Twenty-five years of groupthink theory and research: lessons from the evaluation of a theory", Organizational Behavior and Human Decision Processes, 73 (2-3), 105-115

Wooldridge, J.M. (2009). Introductory Econometrics: A Modern Approach. South Western College, U.S.

Weill, P. O., (2007), "Leaning Against the Wind”, Review of Economic Studies, 74, (4), 1329 1354

Westhead, P. and Cowling, M., (1997) "Performance contrasts between family and non-family unquoted companies in the UK", International Journal of Entrepreneurial Behaviour \& Research, Vol. 3 Issue: 1, pp.30-52, https://doi.org/10.1108/13552559710170892

\section{Appendix - 1: Names of the Scheduled Banks}

\section{Scheduled Banks Operating in Bangladesh - 2012}

\section{A. State Owned Commercial Banks (SOCBs)}

1. Agrani Bank Limited.

2. Janata Bank Limited.

3. Rupali Bank Limited.

4. Sonali Bank Limited. 


\begin{tabular}{|c|c|}
\hline \multicolumn{2}{|c|}{ B. Specialized Bank(SDBs) / Development Financial Institutions (DFIs) } \\
\hline \multicolumn{2}{|c|}{$\begin{array}{l}\text { 1. Bangladesh Krishi Bank Ltd. } \\
\text { 2. Rajshahi Krishi Unnayan Bank Ltd. } \\
\text { 3. Bank of Small Industries and Commerce Bangladesh Ltd. } \\
\text { 4. Bangladesh Development Bank Ltd. }\end{array}$} \\
\hline \multicolumn{2}{|c|}{ C. Private Commercial Banks (PCBs) } \\
\hline i) $1^{\text {st }}$ Generation Conventional PCBs & i) $1^{\text {st }}$ Generation Islamic Shariah based PCBs \\
\hline $\begin{array}{l}\text { 1. AB Bank Ltd. } \\
\text { 2. National Bank Ltd. } \\
\text { 3. The City Bank Ltd. } \\
\text { 4. United Commercial Bank Ltd. } \\
\text { 5. Pubali Bank Ltd. } \\
\text { 6. Uttara Bank Ltd. }\end{array}$ & $\begin{array}{l}\text { 1. Islami Bank Bangladesh Ltd. } \\
\text { 2. ICB Islamic Bank Ltd. }\end{array}$ \\
\hline $\begin{array}{c}\text { ii) } 2^{\text {nd }} \text { Generation Conventional PCBs } \\
\text { 1. IFIC Bank Ltd. } \\
\text { 2. Eastern Bank Ltd. } \\
\text { 3. NCC Bank Ltd. } \\
\text { 4. Prime Bank Ltd. } \\
\text { 5. Dhaka Bank Ltd. } \\
\text { 6. Dutch Bangla Bank Ltd. } \\
\text { 7. Bangladesh Commerce Bank Ltd. } \\
\text { 8. Southeast Bank Ltd. }\end{array}$ & $\begin{array}{l}\text { ii) } 2^{\text {nd }} \text { Generation Islami Shariah based PCBs } \\
\text { 1. Al-Arafah Islami Bank Ltd. } \\
\text { 2. Social Islami Bank Ltd. }\end{array}$ \\
\hline $\begin{array}{l}\text { iii) } 3^{\text {rd }} \text { Generation Conventional PCBs } \\
\text { 1. Mercantile Bank Ltd. } \\
\text { 2. Standard Bank Ltd. } \\
\text { 3. One Bank Ltd. } \\
\text { 4. Mutual Trust Bank Ltd. } \\
\text { 5. Premier Bank Ltd. } \\
\text { 6. Bank Asia Ltd. } \\
\text { 7. Trust Bank Ltd. } \\
\text { 8. Jamuna Bank Ltd. } \\
\text { 9. BRAC Bank Ltd. } \\
\end{array}$ & $\begin{array}{c}\text { iii) } \mathbf{3}^{\text {rd }} \text { Generation Islami Shariah based PCBs } \\
\text { 1. EXIM Bank Ltd. } \\
\text { 2. First Security Islami Bank Ltd. } \\
\text { 3. Shahajalal Islami Bank Ltd. }\end{array}$ \\
\hline \multicolumn{2}{|c|}{ D) Foreign Commercial Banks (FCBs) } \\
\hline \multicolumn{2}{|c|}{$\begin{array}{l}\text { 1. Standard Chartered Bank Ltd. } \\
\text { 2. State Bank of India } \\
\text { 3. Habib Bank Ltd. } \\
\text { 4. Citi Bank, N.A. } \\
\text { 5. Commercial Bank of Ceylon Ltd. } \\
\text { 6. National Bank of Pakistan } \\
\text { 7. Woori Bank Ltd. } \\
\text { 8. The Hong Kong \& Shanghai Banking Corporation Ltd. } \\
\text { 9. Bank Al-Falah Ltd. }\end{array}$} \\
\hline Source: Bangladesh Bank Web & 2012 (www.bangladesh-bank.org) \\
\hline
\end{tabular}

\section{Appendix - 2: Quotations from Interviews}

\begin{tabular}{|l|l|l|l|}
\hline Generation & Position & Quotations Taken from Mahbub (2016) & Page no. \\
\hline Generation 1 & $\begin{array}{l}\text { Managing } \\
\text { Director }\end{array}$ & $\begin{array}{l}\text { “...more than half of the board members are from his } \\
\text { family... got connection with most of the politicians... top }\end{array}$ & P. 237 \\
\hline
\end{tabular}




\begin{tabular}{|c|c|c|c|}
\hline & & $\begin{array}{l}\text { officials of the BB salute them due to power... considering } \\
\text { these, fighting for the right of depositors and shareholder is } \\
\text { mere stupidity... ... they will retain me as long as I play } \\
\text { with their tunes and will kick me off in the next minute if I } \\
\text { act differently... ethics, honesty, dedication - are just } \\
\text { dictionary words to them..." }\end{array}$ & \\
\hline Generation 1 & Head of Credit & $\begin{array}{l}\text { "Sometimes, I feel that we are like monkeys ... get the } \\
\text { instruction from above and act upon that ... no site visiting, } \\
\text { no evaluation of proposal, not checking the compliance } \\
\text { issues, do not worry about collaterals given or not... just } \\
\text { follow the order and send the memo to the board quickly" }\end{array}$ & P. 208 \\
\hline Generation 1 & Head of Credit & $\begin{array}{l}\text { "...all rules and regulations are applicable to general people } \\
\text { but not applicable to the villagers' of the BoDs or directors' } \\
\text { relatives or the ones who they want..." }\end{array}$ & P. 218 \\
\hline Generation 2 & Head of Credit & $\begin{array}{l}\text { “... Board members of } 1^{\text {st }} \text { Gen PCBs have the sentiment of } \\
\text { possessiveness and the feeling of inheritance ... all most all } \\
\text { NPL are resulted from their favoured decisions against the } \\
\text { risk warning by the Credit Division } \ldots \text { however, this } \\
\text { tendency is least apparent in } 2^{\text {nd }} \text { and } 3^{\text {rd }} \text { Gen PCBs as the } \\
\text { BoDs are business conglomerates from different } \\
\text { backgrounds..." }\end{array}$ & P. 236 \\
\hline Generation 2 & $\begin{array}{l}\text { Managing } \\
\text { Director }\end{array}$ & $\begin{array}{l}\text { "...they entered into a new system of competition with } \\
\text { traditional experiences which are not dynamic and } \\
\text { somehow manual in nature... making the organization less } \\
\text { productive... in the era of computers you can't work } \\
\text { completely relying on calculators..." }\end{array}$ & P. 239 \\
\hline
\end{tabular}

